\title{
Rafiq Khoury, Rainer Zimmer-Winkel (eds.), Christian Theology in Palestinian Context, Berlin, AphorismA 2019, 512 p., ISBN: 978-3-8657-5049-5
}

\section{Michael Azar*}

Plagued by the sense that historic Christian anti-Judaism had provided fertile ground for Nazi anti-Semitism, numerous European and North American Christian churches and organizations after World War II took unprecedented steps toward reforming their teachings on Jews and Judaism. As this new, less internecine, relationship between Christians and Jews grew, it increasingly came to reflect not only a Western religious context but a Western political context as well. More positive and sympathetic approaches toward the People of Israel led, in other words, to greater devotion to the State of Israel and Zionism. As the result (and in rarer cases, the cause) of this new religious/political relationship, Western Christian theological reflection regularly examined scriptural themes such as God's covenantal fidelity, the biblical promise of the land, and the chosenness of Israel. Yet, as Western Christians laudably sought to appreciate Jewish perspectives and concerns-in most cases, genuinely for the first time-they regularly overlooked, if not outright demonized, those adversely affected by the new relationship: Palestinians.

Beginning especially in the 1980s, Palestinian Christian theologians sought to change this primarily Western (Christian and Jewish) discussion, and, in many ways, the present collection of essays is a convenient, Englishlanguage culmination of those decades of effort. Aptly named, the collection provides not so much token Palestinian "voices" or "contributions" to a theological discussion whose terms are generally set by Western concerns (political and religious), but it serves instead to show why in the "Palestinian context" the paradigms of "Christian theology" of the last few decades should be revised. How can one theologize, it asks, about such matters as the biblical promises of the land while ignoring the people who have for millennia called it home?

Rafiq Khoury's introductory essay surveys the historical, cultural, religious, and political elements that make up the "Palestinian context" for which the book is named. Evidenced here and throughout the collection is the very real effect that ancient events (whether Babylonian occupation or Ottoman laws) continue to have on Palestinian beliefs about themselves and their interaction with others (a point many seem more willing to grant to

\footnotetext{
* Michael G. Azar, PhD, Associate Professor, Graduate Director, Department of Theology/Religious Studies, University of Scranton, 800 Linden St., Scranton, PA 18510, USA, michael.azar@scranton.edu.
} 
Jewish culture, but not Palestinian). Elias Chacour in particular demonstrates the necessity of Palestinians and Israelis learning the historical "narrative" of the other-especially the real narrative of "suffering" in which they both have shared and about which, as a Palestinian, he speaks personally. A handful of other essays foreground aspects of this Palestinian context, whether its state of "crisis" (Peter Du Brul), its cultural heritage, hopes and challenges (Rifat Odeh Kassis), or, simply, its iconography (Pier Giorgio Gianazza). Together, these essays introduce to Western readers in particular what makes the Palestinian context both beautifully unique and lamentably difficult.

Each essay in the collection, in varying ways, directly and indirectly, highlights the central role that the Bible has in Palestinian theological reflection, not simply on account of their being Christian but, more uniquely, on account of their being Palestinian: they are the people of the book and the land. Mitri Raheb's essay makes especially clear (along with Michel Sabbah's) that Palestinian theological reflection, both by choice and necessity, is devoted toward rescuing their Scriptures (the Old and New Testaments) from trends of "political manipulation" in which they have often been at best ignored and at worst demonized. Three authors (Naim Ateek, Yohanna Katanacho, Viola Raheb) consider directly the ways that the Old Testament in particular can and has been used against Palestinian Christians, but also the ways that the very same texts can become sources of liberation, justice, and peace. Michel Sabbah's essay examines more broadly the biblical themes which have preoccupied Jewish-Christian reflection elsewhere: election, covenant, promises, and the gift of the land. Each of these essays stresses the universal intentions of Israel's chosenness in the Bible.

Moving beyond specific biblical passages, other essays explore themes in Christian theology more broadly. Munther Isaac directly confronts the fact that much of Christian theology-whether Christian Zionism's demonization of Palestinians or other Christian theological oversight of Palestinians entirely (particularly within Jewish-Christian relations)-has contributed to deep injustices in the land and explores, conversely, how Christian theology can contribute to the promotion of justice. Immediately following Isaac's essay, David Neuhaus offers a clear and important overview of Zionism, its differences with Christian Zionism, and ways that Christianity in the Holy Land can confront and meet the hostility of Christian Zionism. Mitri Raheb's essay shows the "Palestinian context" of theology to be one unlike much of the rest of the Christian world, in that the local people have more often than not been subjected to a foreign empire, in which they have time and again learned to ask difficult theological questions about God's providence and liberation. And, finally, Jean Zaru offers a personal and informed 
approach to nonviolent resistance that leads not merely to a cessation in fighting but sulha (Arabic for "reconciliation").

Four essays explore the distinctiveness of interreligious and multi-cultural encounters in the Holy Land. Jamal Khader's review of Christian-Jewish relations shows why such relations on an international level are different from, and therefore cannot dictate the terms of, such relations in the Holy Land, where the Jewish-Christian dynamic is, in most ways that matter, reversed, and where one cannot so easily set aside "political matters" for the sake of gentler conversations. Geries Khoury considers Christian-Muslim dialogue in the Holy Land and, in particular, the way in which it can promote more fruitful Arab unity. Rafiq Khoury hones in on aspects of and the means toward more mutually beneficial and informed relations between Arab and Christian cultures. In his essay on the Jewish-Christian-Muslim trialogue, Munib Younan further demonstrates a point nonetheless evident in the previous three as well-that in a seemingly black and white land (Israeli vs. Palestinian, Jew vs. Arab, Christian vs. Muslim), there is much gray in the ways that people actually interact with each other "on the ground"-many of which would undoubtedly surprise Western readers and visitors more formed by stereotypical or propagandic portrays of "the conflict." Younan's own life exhibits well the gray: he, a Palestinian Lutheran bishop who, though deeply opposed to the Occupation, once called a close Jewish friend to check on the wellbeing of the latter's daughter while on military duty in Gaza.

This collection of essays both conveys and itself serves as an example of ecumenical cooperation in a unique and difficult context. It is thus fitting that Frans Bouwen, as a final "annex" to the collection, addresses the ecumenical situation in the Holy Land. His essay, furthermore, highlights the centrality of the Greek Orthodox tradition in the history of Christianity in the Holy Land and thereby unwittingly highlights an unfortunate gap in this collection: a contribution from an Orthodox writer offering a regional Orthodox perspective. The book concludes with a collection of primary texts (chiefly statements from Palestinian Christian bodies, along with a couple of brief explanatory essays) which have formed the most significant public face of Christian theology in a Palestinian context-most famously, perhaps, the Kairos Document of 2009-as well as a much-appreciated list of further sources.

This collection can rightfully serve as an introduction to the major themes and people (at least as they are known in the anglophone world) of Palestinian theology in the last few decades. To that end, a few changes would have made the collection a bit more accessible. For example, the table of contents is not found until the end of the book; there is no introductory essay that surveys the collection's individual parts, and there appears to be 
no organizing principle according to which the essays are ordered (the order in which I have addressed them is not the order in which they appear in the book). Some sort of thematic or chronological grouping would make the collection more useable for those unfamiliar with its contributors.

Nonetheless, the collection overall accomplishes what it had intended: to offer a diverse snapshot of what it means to think theologically in a Palestinian context, where Christians share a similar heritage as their Muslim neighbors and where the dynamic of power between Jew and Christian is the opposite from what it has been in most other periods and places in the world, especially those places where much of Christian theological approaches to Islam and Judaism (and the geopolitical struggles in the Middle East) continue to be formed. The essays demonstrate that the Palestinian/Israeli "conflict" provides the majority context of Christian theology in the Holy Land (how could it not?), but that the "conflict" at the same time does not define the limits of theology there, as if Palestinian theology should have little to say in matters not directly related to the "conflict." Whatever the case, the collection in the very least challenges common theological tendencies elsewhere that variably ignore the Palestinian context, demonize Palestinians themselves, or mischaracterize Palestinian theologians as anti-Semitic or anti-Jewish (or as seeking to "delegitimize Israel"). While theologies and theologians to come out of the Palestinian context are by no means perfect, and the collection's lack of an Orthodox perspective suggests that this exhibits only $a$, not so much the, Palestinian context, this collection aptly challenges the tendency of too many theologians in the West who mention Palestinian theology only to criticize its achievements or spotlight little more than its missteps. 